\title{
EU Programmes' Financial Support to SMEs: Reducing the Differences Under the View of Funding the Innovation and Key Technologies
}

\author{
Athanasios G. Panagopoulos ${ }^{1}$ \\ ${ }^{1}$ Accounting and Finance Department, University of Macedonia, Thessaloniki, Greece \\ Correspondence: Athanasios G. Panagopoulos, PhD, Accounting and Finance Department, University of Macedonia, \\ 64 Anatolikis Romilias Str., Glyfada, Attica, GR165 62, Greece. Tel: 30-694-471-9671.
}

Received: October 2, 2020

Accepted: November 16, 2020

Online Published: November 24, 2020

doi:10.5430/ijba.v11n6p74

URL: https://doi.org/10.5430/ijba.v11n6p74

\begin{abstract}
Under their adaptable production structures and quick adjustment to technological innovations in the world economic developments, SMEs are among the most important wheels of both the EU economy and the whole global economy. This paper examines, the significance and the size of SMEs which contribute to production capacity, financial investments, economic development, and EU/national income, as well as employment and management and other areas, are combined and studied using a set of data and information; therefore, the EU Programmes which provide financial support are mainly organized regarding the financial issues of SMEs are also introduced. Under this logic, the parts of the funding programmes offered to SMEs within the EU budget over the budget period from 2014 to 2020 in the Union's budget are assessed, and recommendations are suggested for the next years 2021-2027, as well. Consequently, banks and/or other financial institutions may not be able to constitute credit products, interest rates, loan amounts and appropriate repayment maturities that are suitable for the needs of SMEs, or most importantly, they may not have sufficient resources to finance specific credits.
\end{abstract}

Keywords: SMEs, budget, development, financial support, investments

\section{Introduction}

As part of the business community, small and medium-sized enterprises undoubtedly contribute to national economic prosperity. They produce an essential part of all products and services. In this way, their financial offer is similar to that of larger companies. Small and medium-sized enterprises, however, have some characteristics which are a small representation of large business cooperatives. They offer special benefits as they create new professions, innovate, strengthen competition, help large companies and adequately produce products and services.

Small and medium-sized enterprises (SMEs), essentially, represent $99 \%$ of businesses in the EU. They provide, actually, the two-thirds of the private sector jobs and contribute much more than half of the total value added created by businesses in the EU. They have approved various action plans to strengthen SMEs, such as the Small Business Act and Horizon 2020 and COSME. The purpose of these Programmes is to increase the competitiveness of SMEs through key technologies, research, innovation, and to provide SMEs with imediate access to finance.

The European Union contributes to the commitment to creating an environment in which business, industry and innovation can thrive. European Union business policy is currently designed to meet the needs of all business circles and their environment. Its history has been shaped by work in the following three key policy areas: Small and Medium Enterprises (SMEs), Innovation and Competitiveness, including the opportunities and benefits of the single market.

The European Union aims to promote entrepreneurship in Europe by contributing to the creation of favorable business conditions. Rewarding and supporting those at risk, as well as promoting methods to improve their access to funding sources, can help start-ups. Innovation is one of the main assets of a knowledge-based economy. The proper use of research and technology, as well as the promotion of competitiveness, are vital to the ability of businesses to grow. Take advantage of the effects of innovation, turning them into competitive business ideas.

Data presented in Figure 1 and Figure 2 shows the amounts of revenues and expenses of the EU budget regarding years 2013 to 2017, as long as, the total EU budget revenues, taking under consideration disbursements taken place in years 2014 and 2020 . 


\section{Literature Review and Research Methodology}

In Figure 1 below it is depicted the variation of the EU's whole budget and income with expenses, as well. However, in Figure 2, the parts of commitments, as long as, the payments compared to total EU expenses are 51\% and $49 \%$.

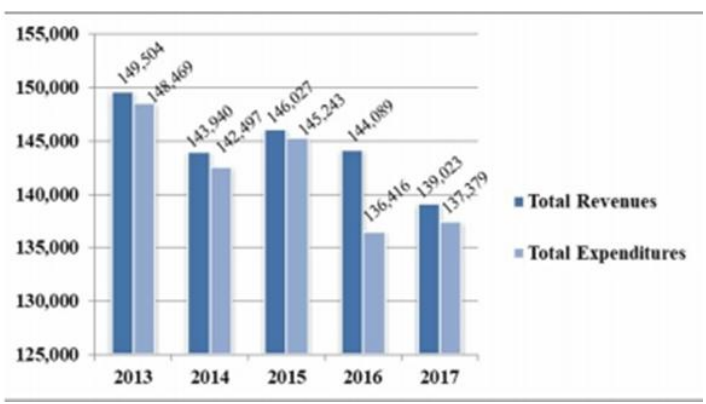

Figure 1. The EU budget with revenues and expenses (2013-2017) (in mlns Euro)

Source: European Commission, $20192^{\text {nd }}$

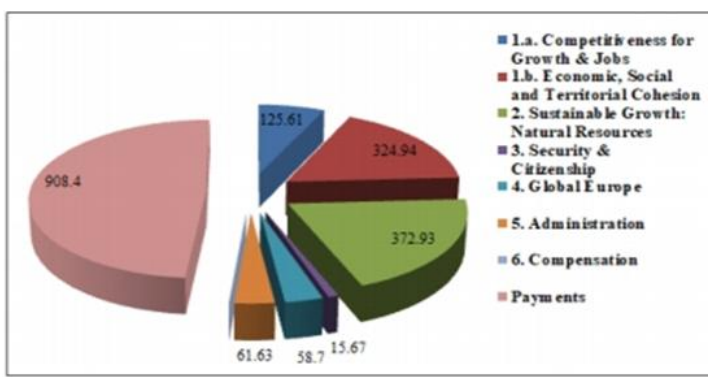

Figure 2. EU Expenses (years 2014 to 2020)

Source: European Council (2019)

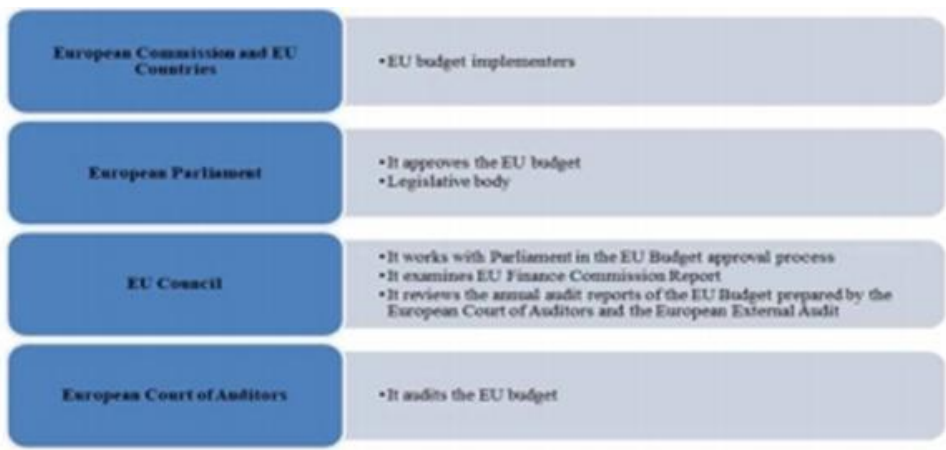

Figure 3. Major factors that contribute in the Process of the EU Budget

Source: European Parliament, 2019

In Figure 3 above are presented the most important key factors that essentially are involved in the implementation, the the auditing processes and the preparation, of the EU budget, using the technique called 'performance-based budgeting'.

In the paper methodoly we've noticed, small and medium-sized enterprises create many of the job opportunities required by a growing population and economy. In fact, it seems that small and medium-sized enterprises are 
creating the "lion's share" of new jobs, while large companies are "reducing" the number of employees and making redundancies. Between 1980 and 1986, companies with less than 20 employees worldwide contributed much more to production growth than companies with 500 employees, or more.

Innovation is one of the main assets of a knowledge-based economy. Proper use of research and technology and promoting competitiveness, as well, are vital to business growth.

The European Union seeks to foster a spirit of innovation in the economy and to ensure that businesses are given every opportunity to benefit from the effects of innovation, turning them into competitive business ideas. A directive on services in the internal market was published in 2006 (Directive 2006/123 / EC) and implemented by all EU Member States in 2009, it is basically described as "small and medium-sized enterprises (SMEs) are non-subsidiary, independent firms which employ fewer than a given number of employees (Bordo et al, 2011). This number varies across countries". The size, annual turnovers, staff headcounts, and annual balance sheets of all kind of SMEs for the EU are depicted in Table 1 below.

The internal market is the area where European companies interact. Despite its success to date, it continues to be hampered by a number of significant obstacles to the free movement of goods and services. The removal of these barriers, the guarantee of market access, the liberalization of sectors such as transport and telecommunications, as well as the simplification of regulations, will allow companies to make the most of the internal market.

Also, in Table 1, the high limit defines as an SME of a 250 staff, as in the EU. The perception that small and medium-sized enterprises create more jobs than large enterprises comes from a study by David L. Birch conducted in the early 1980s at the Massachusetts Institute on SME Contribution to Job Development. Although there were doubts about the findings of the research, after a recent research these conclusions were confirmed (OECD, 2005). Acs-Audretsch, for example, found that between 1976 and 1986, small and medium-sized enterprises created jobs in the manufacturing sector, while the number of production positions in large enterprises decreased by 100,000. According to the Acs-Audretsch survey, Birch's findings, which concerned the number of jobs mainly coming from small and medium-sized enterprises, were substantiated.

Table 1. What is the definition of SMEs in the EU area

\begin{tabular}{llllll} 
Size & $\begin{array}{l}\text { Staff } \\
\text { Headcount }\end{array}$ & EU & $\begin{array}{l}\text { Annual } \\
\text { Turnover }(\boldsymbol{\epsilon})\end{array}$ & EU & $\begin{array}{l}\text { Annual Balance } \\
\text { Sheet (€) }\end{array}$ \\
Micro-Enterprise & $<10$ & & $\leq 2$ millions & & $\leq \mathbf{2}$ millions \\
\hline Small-Enterprise & $10-50$ & and & $\leq 10$ millions & or & $\leq \mathbf{1 0}$ millions \\
\hline Medium-Enterprise & $\mathbf{5 0 - 2 4 9}$ & & $\leq \mathbf{5 0}$ millions & & $\leq \mathbf{4 3}$ millions \\
\hline
\end{tabular}

Source: KOSGEB (2019 1 $\left.1^{\text {st }}\right)$

\section{SMEs' Funding Support Shemes Within the Context of the EU Budget}

\subsection{Credit Schemes Given by the European Investment Fund (E.I.F.)}

In order to achieve the above-mentioned business policy objectives, the European Union has developed various methods of strategy. The new BEST (Business Environment Simplification Task Force) process brings together a variety of activities that were previously individual, and includes benchmarking, seminars, meetings and peer review. It is based on statistics, surveys and analyzes that help to form a clear picture of the business environment and existing problems.

SMEs many times fail to secure the necessary funding through banking and secondary markets. In recent years, much progress has been made in improving the way to receive credit for SMEs, through the provision of banking loans and venture capital. The European financial institutions - the EIB and the EIF - have stepped up their SME activities.

But the SBA still sees access to finance as the second biggest problem facing individual SMEs. In November 2011, the Commission proposed an "action plan to improve SMEs' access to finance". Launching a more business-friendly society, with this action plan, is all over the world. Attitudes towards entrepreneurship and failure should be more positive. The realization of this goal is based on those on whom the entrepreneurs of today and tomorrow depend. It is also about upgrading the role played by social economy companies by acting in favour of society as a whole. 


\subsection{Credits Schemes Given by the European Investment Bank (E.I.B.)}

Small and medium-sized enterprises, especially in their early stages, rarely have the opportunity to be systematically informed about the diverse forms of support provided by EU programs. They are also not always able to fully assess innovation or commercial potential of their products and take advantage of new business opportunities that arise, especially when it comes to areas other than those they know well (Aslan, 2008: 43).

Eurozone small and medium-sized enterprises (SMEs) (Table 2) have seen a rapid deterioration in their economic environment amid the coronavirus pandemic, according to a European Central Bank (ECB) survey on business access to finance. The survey covering the period from October 2019 to March 2020 shows that SMEs reported a decrease in their turnover (in net terms $-2 \%$ from $20 \%$ in the previous six months). This is the first turnover recorded in the ECB's semi-annual survey conducted since 2014. SMEs also reported a sharp decline in profitability (in net terms $-15 \%$ from $-1 \%$ in the previous survey), which occurred in all countries and sectors. SMEs continued to report a lack of skilled labor available as their main concern ( $24 \%$ of respondents compared to $28 \%$ in the previous survey), followed by difficulty in finding customers (21\% vs. $22 \%)$.

The SBA and the Commission Communications entitled "Towards a Single Market Act - Towards a Highly Competitive Social Market Economy" (COM (2010) 0608) and "Single Market - Act II" (COM (2012) 0573) emphasize the need for continuous improvement of the conditions under which companies operate in the single market. Various initiatives and measures exist or have been designed to facilitate the establishment and operation of SMEs in the internal market. Derogations have been granted to SMEs in many areas, for example in terms of competition rules, taxation and company law.

The horizontal nature of entrepreneurship requires a coordinated approach. This is especially true for public administrations at all levels. The latter should be better coordinated with business owners to identify priorities in the context of empowerment and entrepreneurship. Some Member States are doing better in promoting entrepreneurship. It would be useful for them to inspire others in the context of the open method of coordination, with which the Commission is laying the groundwork for countries to exchange their best practices. Under this regulation, SMEs can benefit from public support of up to $€ 7.5$ million.

In terms of access to finance (Figure 4), the net share of SMEs reporting an improvement in bank loan availability remained positive, but fell to $5 \%$ from $10 \%$. This is attributed to the willingness of banks to lend (11\% vs. 14\%). However, for the first time since September 2014, Eurozone SMEs perceived their financial situation as a factor hindering their access to finance (-18\% from 5\%). In addition, the overall economic outlook was considered to have a strong negative impact (-30\% from -13\%), which has not been the case since March 2013 (Charbit, 2011). According to the ECB, SME responses to the expected availability of external funding are useful in assessing the potential impact of the coronavirus pandemic in the near future. Overall, they show a decrease in expectations regarding the availability of bank loans in the Eurozone (-11\% from $4 \%$ ) with the level of deterioration differing between countries. Italian SMEs recorded the largest deterioration in pure terms (-13\% from 9\%), followed by French and Spanish SMEs (-9\% and -12\% from 8\% and -1\%, respectively) (Ersan 2010).

\section{Analysis of the EU Financing Programmes}

The European Union's commitment to helping to create an environment in which businesses, industry and innovation can thrive is formally enshrined in Article 157 of the EC Treaty. EU business policy is currently designed to: meets the needs of all business circles and their environment (Ministry of EU, 2014).

Table 2. Sectors mainly supported by European Investment Bank (E.I.B.)

\section{Sectors Supported by EIB}

Agriculture, food and rural Digital economy development

Education and training

Energy

Forestry

\begin{tabular}{lllll}
\hline Health and life science & $\begin{array}{l}\text { Regional } \\
\text { development }\end{array}$ & Trans-European Networks & Transport & Urban agenda \\
\hline
\end{tabular}

Water and wastewater management

Source: EIB, $\left(20192^{\text {nd }}\right)$ 


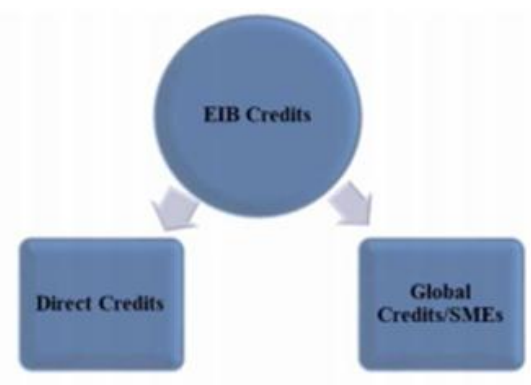

Figure 4. The EIB credit schemes, project size terms

It is worth referencing examples of SME networks which include, first, supporting services for SMEs in the EU, for example, the Enterprise Europe Network, the Internal Market Troubleshooting Network (SOLVIT), and the portal "Your Europe - Business", "SMEs and the Environment", and "Handling Chemicals: National REACH Support Offices". Moreover, supporting innovation and research includes the "European IPR Support Office", "SME Techweb", "IPR SME Support Office for China", the "Network of European Business Innovation Centers (KEK)", the "European Network for Workplace Innovation" and "Gate2Growth".

Facilitating innovation and entrepreneurship is a key principle in all areas of business policy. The European Commission is central to ensuring that innovation policy is consistent and coherent across the European Union, to evaluating performance, to disseminating best practice, and to highlight the lessons learned from any failure of market economy justifying state intervention. The rules on state aid and other forms of financing are more flexible for small and medium-sized enterprises than for large enterprises. Entrepreneurs, especially Small and Medium Entrepreneurs, can also receive assistance in finding partners through the network of innovation centers in more than 30 countries, with partial funding from the Commission.

Studying Figure 5, it is worth noticed that the greatest expenditure item of the EU's total budget expenditures over the period 2014-2017 is used by the Horizon2020 Programme.

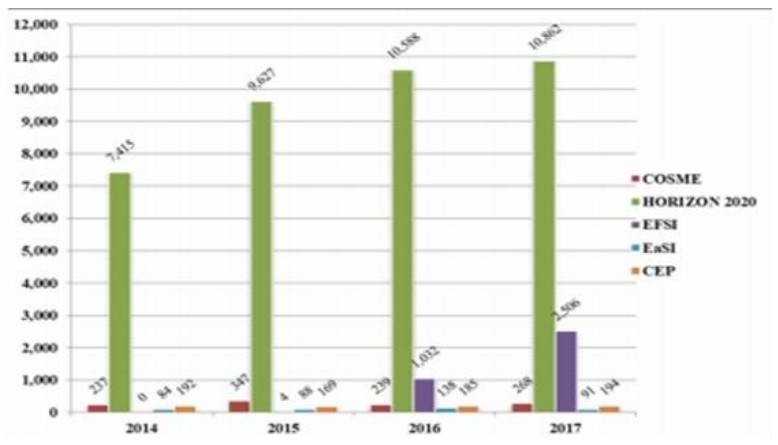

Figure 5. European Union financing programmes compared to EU's total expenditures (2014 to 2017, mlns Euro)

Source: EC, $\left(20192^{\text {nd }}\right)$

In particular, the Commission funds programs that address best business practice and help to frame its policies. To achieve these goals, the European Commission has facilitated the creation of Euro Info Centers that will inform, assist and advise businesses on all Community issues, including funding assistance. The European Commission does not directly support businesses. Invitations to tender are published in the Official Journal of the European Communities and are funded by the European Investment Fund.

The COSME program will act as a means of financing bank guarantees to help them provide more loans and leasing to SMEs (Figure 6). The impact will be substantial, as due to the leverage effect of the COSME program, for every 
euro invested in loan guarantees, there is 30 euros of financing for SMEs. These guarantees will typically help many SMEs that might otherwise have been unable to obtain funding due to a lack of adequate collateral.

Part of COSME's budget will also invest in funds that provide venture capital for the expansion and development of SMEs, especially those operating across borders. The fund managers will actually operate on a commercial basis to ensure that investments are mainly focused on SMEs with the greatest growth potential. It is expected that about 500 companies will receive equity, while the total investment volume will reach up to 4 billion euros and will attract further funding from joint investments with other public and private sources.

\section{The EU Programme Regarding the Competitiveness of Enterprises and Small and Medium-Sized Enterprises (or the "COSME Programme")}

COSME (Competitiveness of Enterprises and SMEs) is the EU program for the Competitiveness of Enterprises and Small and Medium-sized Enterprises, with a duration from 2014 to 2020 and a budget of 2.3 billion euros. With a budget of $€ 2.3$ billion for the spanning years 2014 to 2020, the COSME program has a mandate to fulfil the following general objectives:

- Improving SMEs' access to equity and debit financing: a equity mechanism for investment in the development phase as well as a loan guarantee mechanism, which will provide SMEs with direct or other risk-sharing arrangements, $€ 1.3$ billion from the COSME budget are available for these financial instruments;

- Improving market access both within the Union and globally: through the Enterprise Europe Network, development-oriented business support services will be provided to facilitate business expansion both in the single EU market and outside the EU;

- Strengthening entrepreneurship with activities such as development of businessmen skills and attitudes, especially between young businessmen and women.

Business policy is coordinated in conjunction with other policies, in particular those for the single market, research and innovation, and the information society. Conversely, when the EU develops policies on trade, education and training or the environment, the impact on business is taken into account.

In Table 3, we can see the COSME Programme's budget which worths about $€ 2.3$ billion, and it aims to promote mainly business culture by encouraging the competitiveness and SME's sustainable development.

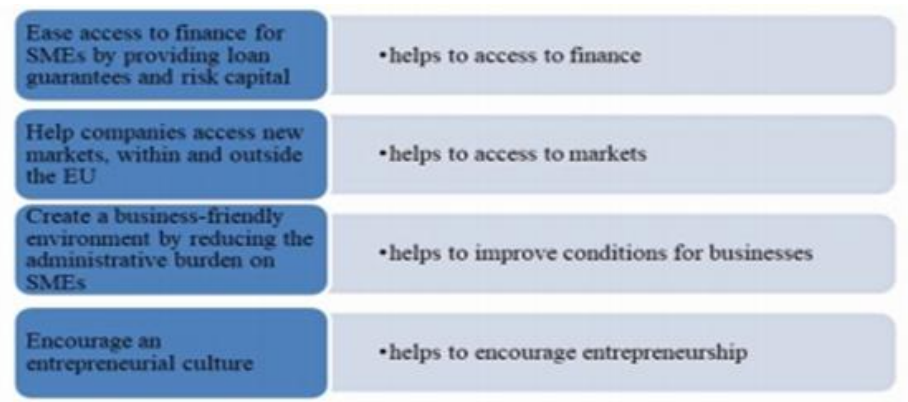

Figure 6. Presentation of the main objectives of the COSME Programme

Source: EU, (2019 $\left.1^{\text {st }}\right)$

Table 3. Important elements of the COSME Programme

\begin{tabular}{lll} 
Elements of the COSME Programme & Budget (Million Euro) & Budget (\%) \\
Access to Finance & $1,, 378 ., 946$ & 60 \\
\hline Access to Markets & $494 ., 122$ & 21,5 \\
\hline Improving Framework Conditions & $252, .807$ & 11 \\
\hline Entrepreneurship and Entrepreneurial Culture & $57 ., 456$ & 2,5 \\
\hline Managerial Costs of the Programme & $114, .912$ & 5 \\
\hline TOTAL & $2,298 ., 243$ & 100 \\
\hline
\end{tabular}

Source: EIF, 2019a 
According to the above objectives, the COSME Programme offers two distinct products aimed by the EIF: "Loan Guarantee Facility (LGF)" and "Equity Facility for Growth (EFG)" (EIF, $20191^{\text {st }}$ ). The LGF offers guarantees and counter-guarantees to credit institutions, investment banks, lenders, brokerage houses, leasing companies, etc., essentially financial intermediaries, selected by the EIF, in order to offer SMEs additional funds and other (such as leasing) opportunities. The LGF supports the access to credit finance for SMEs, but especially for those which have difficulties to access banking lending, and contributes to increase the SMEs to be financed by the aforementioned financial schemes.

The COSME program is an extension agreement that will allow the EIB to direct $€ 500$ million in financing to more than 1,900 small businesses in Greece over three years. The EIF, with the support of the European Commission, will provide guarantees to the EIB under the COSME program, which will enable the Bank to significantly reduce its collateral requirements, thus facilitating corporate lending.

Beneficiaries of the Program are as follows : The Program is addressed to Small and Medium Enterprises, of all economic sectors and any legal form, which meet the following conditions (with exceptions): They are based and operate in Greece or in EU Member States. and in COSME partner countries. Also, they do not belong to any of the ineligible areas of activity.

Purpose and types of funding are:

- Long-term financing of investment projects to cover acquisition costs and / or creation of fixed assets

- Medium-term working capital financing for the development and expansion of business activity.

- Short-term financing to cover needs, which are related to the business / transaction circuit of the company.

Funding Amount:

- Up to Euro 150,000 /

- 'Over $€ 150,000$, if the SME does not meet any of the InnovFin Program innovation criteria.

In this case the maximum amount of funding is as follows:

- For a period of up to 5 years, up to Euro 3,000,000 (excluding road freight SMEs, where the maximum amount is Euro 1,500,000).

- For a period of more than 5 years and up to 10 years, up to Euro 1,500,000 (except for road freight SMEs, where the maximum amount is Euro 750,000).

Warranty period:

The guarantee of E.T $\alpha . E$. is provided for up to ten (10) years.

Forms of Financing:

- Investment Loan: From 12 to 120 months

- Moving Development Capital: From 12 to 72 months

- Revolving Working Capital (Mutual Account): With 12 months recycling and possibility of annual renewal, with a maximum total duration of five (5) years.

\section{InnovFin Programme (The Horizon 2020)}

The InnovFin SMEG Guarantee Facility is one of the financial instruments of the European Horizon 2020 Program, which, in addition to the grants awarded under the Program, contributes to the implementation of EU policies aimed at strengthening Research and Innovation.

The InnovFin SMEG mechanism is implemented at European level by the European Investment Fund (EIF), which provides guarantees (and counter-guarantees) to selected financial intermediaries to cover any non-repayments arising from new portfolios that tool. The guarantee rate reaches up to $50 \%$ per eligible transaction. Banking facilities can take the form of a full-time loan or working capital loan and can finance assets (including goodwill), working capital or stock transfers.

Studying carefully Table 4 , it is easily extracted that an amount of $€ 24,441$ million has been reserved to the "Excellent Science" spanning the period from 2014 to 2020. Within the scope of the Excellent Science, the ERC, supports specific research methodology which is carried out particularly by consultants, experts, speciliasts and other researchers aimed by their staff, providing a total amount at least $€ 13,095$ million. As being an outstanding project in 
the scope of the Horizon 2020 Programme, Industrial Leadership aims mainly to increase employment and working opportunities by creating new jobs.

For example in Greece, more than 5,000 small and medium-sized enterprises are expected to benefit from loans totaling 640m euros. The European Investment Fund (EIF) and the National Bank of Greece (NBG) have signed three guarantee agreements worth $640 \mathrm{~m}$ euros that improve access to finance for small and medium-sized enterprises (SMEs) in Greece. These agreements are supported by the European Strategic Investment Fund (EFSF), a central pillar of the Investment Plan for Europe (Juncker Plan).

Under the new InnovFin agreement, the EIB will provide favorable financing to innovative SMEs and small and medium-sized enterprises for a period of two years. The EIF guarantee is provided under the "InnovFin - EU Funding for Innovation" initiative, with financial support from the EU's Horizon 2020 research and innovation program. Under the agreement, EU support for innovative Greek companies is expected to create a loan portfolio of $100 \mathrm{~m}$ euros.

Table 4. The predicted budget for Excellent Science (2014 to 2020, in mln Euro)

\begin{tabular}{ll} 
Excellent Science & Budget (Million Euro) \\
\hline European Research Council (ERC) & 13.095 \\
\hline New and Developing Technologies & 2.696 \\
\hline The Marie Skłodowska-Curie Actions (MSCA) & 6.162 \\
\hline Research Infrastructure (including e-infrastructures) & 2.488 \\
\hline TOTAL & 24.441
\end{tabular}

Source: Ministry of EU (2019)

Table 5. Industrial Leadership-Predicted Budget (2014 to 2020, in mln Euro)

\section{Industrial Leadership Budget (Million Euro)}

\begin{tabular}{ll} 
Facilitative and Industrial Technologies & 13.557 \\
\hline Access to Risk Capital & 2.842 \\
\hline Innovation Programme in SMEs & 616 \\
\hline TOTAL & 17.015 \\
\hline
\end{tabular}

Source: Ministry of EU (2019)9

We can notice in Table 5 various details of budgets which are reserved mainly to industrial leadership spanning the years 2014 to 2020 within the scope of the specific Programme. Moreover in Table 5, $€ 17.015$ million from budget is given to industrial leadership item but under the Horizon 2020 Programme, and another $€ 616$ million is provided to SMEs under the Innovation Programme. The $3^{\text {rd }}$ project, which is 'social problems', concerns the development of solutions to various social challenges. Such problems in society are considered into seven main frameworks-categories, and other various amounts which, in turn, are given for each problem (EC, 2014). Seeing the Table 6 we can notice that shows details of such social problems and agreements, as well, and the budget amounts are reserved to them under the framework of the Horizon2020 Programme.

These agreements were signed in the framework of the European Commission's InnovFin initiative, which were supported by the EU research and innovation program. "Horizon2020". The InnovFin initiative allows participating banks to lend to innovative companies with the support of a guarantee provided by the European Investment Fund.

The 800 million euros will be added to the 820 million euros that were approved for SMEs in the above countries two years ago, bringing the total loans to 1.62 billion euros. The plans and agreements approved so far under the Juncker package are expected to mobilize a total investment of around 410 billion euros. To date, 952,000 SMEs in the 28 Member States have benefited from funding. 
InnovFin SME Guarantee Facility provides guarantees to improve access to loan finance for innovative small and medium-sized enterprises and medium-sized companies (less than 500 employees). The facility is managed by the EIB and is available through financial intermediaries - banks and other financial institutions - in the EU Member States. And in associated third countries.

In Table 6, if we compare other social problem items between them, it can be extracted that the greater financial budget amount is reserved mainly for "Health, Demographic Change, and Welfare" and "Smart, Clean and Integrated Transportation" items, as well (Wiener et al, 2018). Along with these key factors, the EU Joint Research Center (JRC) programs regarding the promotion and development of the excellent scientific quality and involvement for the society itself, are also included in the Programme Horizon2020 (Ministry of E.U., 2019).

\section{Analysis of the European Fund for Strategic Investments (E.F.S.I.) Programme}

The European Fund for Strategic Investments (EFSI) is a Programme that provides, essentially, funds under the EIF to aim, both the venture capital (V.C.) of SMEs and medium-sized enterpises, as well, through EU. The EFSI clearly supports various EU financial Programmes (ie, "Horizon 2020" and "COSME").

EFSI is a joint initiative of the European Commission and the EIB. It forms the basis of the EU investment plan, also known as the "Juncker Plan", which initially aimed to raise $€ 315$ billion from public and private resources to finance strategic investments.

Table 6. Social problems and predicted budget (2014 to 2020, in mln Euros)

\begin{tabular}{ll} 
Social Problems & Budget (Million Euro) \\
Health, Demographic Change, and Welfare & $\mathbf{7 . 4 7 2}$ \\
\hline $\begin{array}{l}\text { Food Safety, Sustainable Agriculture and Forestry, Marine, Maritime and Inland } \\
\text { Waters Research and Bio-Economics }\end{array}$ & $\mathbf{3 . 8 5 1}$ \\
\hline Safe, Clean and Productive Energy & $\mathbf{5 . 9 3 1}$ \\
\hline Smart, Clean and Integrated Transportation & $\mathbf{6 . 3 3 9}$ \\
\hline Climate Change, Environment, Resource Efficiency and Raw Materials & $\mathbf{3 . 0 8 1}$ \\
\hline Europe in Changing World- Comprehensive, Innovative and Reflective Societies & $\mathbf{1 . 3 0 9}$ \\
\hline Secure Societies - Protecting Freedom and Security of Europe and its Citizens & $\mathbf{1 . 6 9 5}$ \\
\hline TOTAL & $\mathbf{2 9 . 6 7 8}$
\end{tabular}

Source: Ministry of EU, 2019

The auditors from the Court of Auditors found that, in part, EFSI support merely replaced funding from other EU and European Investment Bank (EIB) sources. Part of the money went to projects that could have been funded by other public or private sources of funding - albeit under different conditions - and most of the investment was made in some of the 15 largest EU Member States through well-established national development funds and banks.

The auditors concluded that the EFSI, from its launch in 2015 to July 2018, managed to raise funds to support additional investment across the EU. They found that, by mid-July 2018, the EIB had approved funding of EUR 65.5 billion, thus exceeding the indicative funding volume of EUR 61 billion expected to be secured. With the support of EFSI, the EIB has managed to quadruple its higher risk financing operations compared to 2014.

The EFSI is a 26b Euro guarantee scheme derived from the EU budget and complemented by a 7.5b EUR reserved amount of the EIB's company capital. Therefore, a total of 33.5b EUR has been given from EFSI, and an additional amount of 500b EUR is going to be provided the lasy months of 2020 (EIB, $20193^{\text {rd }}$ ). In Figure 7, the four target groups aimed by EFSI are shown analyzed by sectors (Table 6).

\section{Analysis of the Programme for Employment and Social Innovation (EaSI)}

The EaSI, is an EU's Programme dedicated to social policy, was primary developed to support objectives such as ensuring qualified and sustainable employment as well as tackling poverty, adequate social protection, and improving the working environment. As presented below in Figure 8, this Programme which has as main scope to move to a more modern social policies and employment, consists of 3 subprogrammes: (1) European Network for 
Employment Services (the EURES), (2) the Microfinance and Social Entrepreneurship and (3) the PROGRESS (Programme for Employment and Social Solidarity).

In addition, the EIF has signed a microfinance guarantee agreement with the EIB under the EU's Employment and Social Innovation Program (EaSI) to support $€ 40$ million to 3,400 micro-borrowers - very small businesses - facing access to lending in the whole country. The EaSI Guarantee program was launched in June 2015, is funded by the European Commission and is managed by the European Investment Fund.

The Employment and Social Innovation Program (EaSI) is an EU-wide funding mechanism aimed at promoting high quality and sustainable employment, ensuring adequate and adequate social protection, combating social exclusion and poverty, and improving working conditions.

The EaSI is managed directly by the European Commission. The program brings together three EU programs that were managed separately from 2007-2013: PROGRESS, EURES and the Progress Microfinance Facility.

As of January 2014, these programs are the three pillars of EaSI, which support:

- The modernization of social and employment policy - PROGRESS axis;

- Occupational mobility - EURES axis;

- Access to microfinance and social entrepreneurship - axis Microfinance and social entrepreneurship.

The total budget for the period 2014-2020 amounts to 919,469,000 euros at 2013 prices.

Objectives are:

- Strengthen the appropriation of EU objectives and coordinate action at European and national level in the fields of employment, social affairs and social inclusion.

- Support the development of appropriate social protection systems and labor market policies.

- Modernize EU legislation and ensure its effective implementation.

- Promoting geographical mobility and enhancing employment opportunities by developing an open labor market.

- Enhance the availability and accessibility of microfinance for vulnerable groups and micro-enterprises, and improve the access of social enterprises to finance.

To achieve these objectives, the EaSI:

- pays special attention to vulnerable groups, such as young people,

- promotes equality between women and men,

- fights discrimination,

- promotes high quality and sustainable employment,

- guarantees adequate and appropriate social protection,

- fights long-term unemployment,

- fights against poverty and social exclusion.

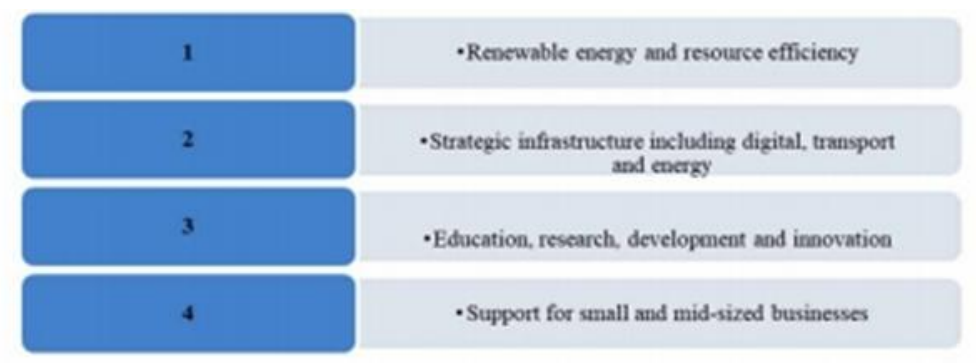

Figure 7. Main target Groups of the E.F.S.I.

Source: EIB, $\left(20194^{\text {th }}\right)$ 


\section{Analysis of the Creative Europe Programme (CEP)}

The CEP Programme, is the programme with the smallets share of the EU's financial supporting programmes, which aims the international cooperation between cultural and other creative sectors (such as museology, architecture, art, cultural heritage, etc.) and promotes, at the same time, innovation and creativity. Culture is at the center of Europe's rich heritage and history and plays an important role in promoting the attractiveness of places and enhancing the uniqueness of a particular site. Culture and creativity can become important drivers and drivers of innovation, as well as an important resource for entrepreneurship. Culture is a key driver for increasing tourism revenue, with cultural tourism evolving into one of the fastest growing tourism sectors in the world. Culture also plays an important role in promoting social inclusion.

For the 2014-2020 programming period, with its strong focus on enhancing competitiveness, growth and employment, it is recommended that national and regional authorities:

- focus the ERDF contribution to supporting new cultural sectors closely linked to innovation and creativity,

- to utilize investments in cultural heritage for the development and support of cooperative formations of the creative industry, e.g. with a focus on enhancing the "user experience" through digital technology,

- Strengthen synergies with other funds, such as the Creative Europe Framework Program, the Enterprise and SME Competitiveness Program (COSME), Horizon 2020, the Framework Program for Research and Innovation, the European Alliance of Creative Branches, national and / or regional programs for the cultural and creative sectors, as well as other possible sources of funding.

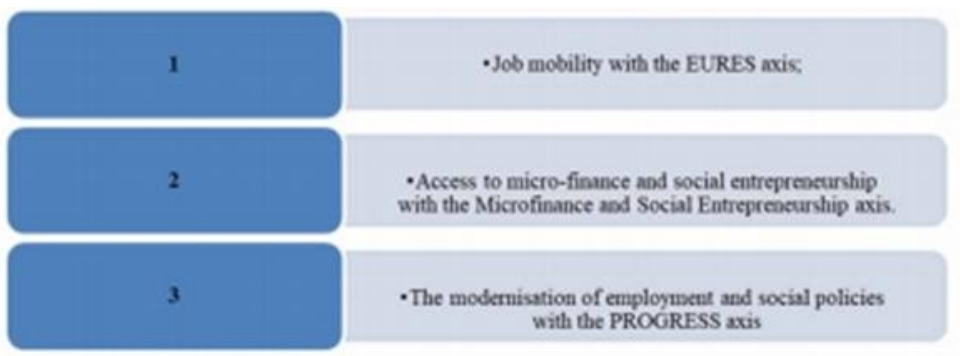

Figure 8. EaSI Programmes (2014 to 2020)

Source: EC, $20194^{\text {th }}$

\section{The Framework, the Objectives and the Strategy Methods of the European Policy}

Business is essential to the Union's economic growth. To build a strong economy, the European Union must cultivate the spirit of entrepreneurship in Europe, and create the conditions that encourage innovative business practices and lead to business creation and growth.

Achieving these goals is vital to achieving the sustainable economic growth needed to support social progress and protect the environment. EU business policy is aimed at the business environment as a whole, and aims to help businesses - regardless of size, legal form or sector - to grow and develop.

Its threefold goal is to promote and facilitate the creation of new businesses, to stimulate the growth and innovative capacity of all businesses through the creation of a dynamic business environment, and to ensure real access to markets in Europe and beyond, for the goods and services offered by these companies.

The European Union aims to promote entrepreneurship in Europe by contributing to the creation of favorable business conditions. Rewarding and supporting those at risk, as well as promoting ways to improve their access to finance, can help start-ups.

The high availability of business support mechanisms, networks and services also plays an essential role in this regard. The creation and growth of new innovative business groups is crucial to supporting and promoting European competitiveness in new knowledge-based industries. This element also advocates the reform of education and training systems in order to develop skills and knowledge in this area. 
Innovation is one of the main assets of a knowledge-based economy. The proper use of research and technology, as well as the promotion of competitiveness, are vital to the ability of businesses to grow. The European Union strives to foster a spirit of innovation in the economy and to ensure that businesses are given every opportunity to benefit from the effects of innovation, turning them into competitive business ideas.

The internal market is the area where European companies interact. Despite its success to date, it continues to be hampered by some significant obstacles to the free movement of goods and services. Eliminating these barriers, guaranteeing market access, liberalizing sectors such as transport and telecommunications, and simplifying regulations will allow companies to make the most of the internal market.

The use of optional rules and flexible regulations is intended to play an ever-increasing role in ensuring that the internal market works to the benefit of European companies while maintaining high standards of environmental and public health.

European Union business policy has reoriented its main concern: in the past it was about immediate action, but now new methods of coordinating national policies and business initiatives are being promoted, as well as evaluating their impact. Member States are encouraged to share their experience and learn from each other, using a whole range of benchmarking methods. Cooperation, with the aim of improving individual and collective performance through the dissemination of best practices, is expected to improve the business environment and to have a beneficial effect on competitiveness.

\section{Conclusion and Further Research}

The search for alternative forms of SME financing is an issue that is of particular concern to governments worldwide. It is noteworthy that the Organization for Economic Co-operation and Development (OECD) has come up with specific general principles - proposals to Member States for policy measures to facilitate SMEs' access to sources of funding. At European Union level, the use of financial instruments through specialized programs to support entrepreneurship and innovation, as well as high-level initiatives such as the European Strategic Investment Fund (EFSI).

In conclusion, the use of financial instruments with the consequent mobilization of public and private resources in combination with the traditional forms of non-repayable state aid (grants), is one of the preconditions for creating conditions for economic growth by strengthening entrepreneurship, both at EU and country level, as in the case of Greece.

In this regard, it is important to form the appropriate framework so that the design and implementation of the necessary policies to facilitate the access of European SME companies, especially SMEs, to sources of funding, on the one hand to overcome the barriers and rivalries between stakeholders responsibilities of public services and on the other hand, to meet the real needs of companies depending on their stage and development prospects.

The above, in order to contribute substantially to the formation of conditions for sustainable economic growth, it is necessary to implement them in a strategic policy framework that the state will not perceive simply as a vehicle to cover market deficiencies, but will highlight its role as a co-investor in taking on a significant part of the risk and uncertainty associated with the implementation of long-term and innovative investment plans by European small and medium-sized enterprises. Contemporary trends in management science and the economics of innovation and entrepreneurship are oriented in this direction, which answer from their own point of view the current questions of the long-term economic crisis.

The EU has developed five financial programmes for supporting SMEs and another five financial programmes in collaboration with EIF and EIB, but in-line with 2014 to 2020 targets, in order to eliminate differences under the view of funding the innovation and key technologies. Spanning period 2014 to 2020, programmes such as the COSME 2020, the EIFS, the HORIZON 2020, the EaSI, the CEP along with the EIF, and the EIB supporting funds, have been established, to reduce the obstacles to investments and to suggest solutions to their financial problems. (European Commission, $20181^{\text {st }}$ ).

A different innovative tool is needed for a new innovative business, for which a capital-type aid from Technology Transfer Institutions or Business Angels might be better suited, from a start-up company in low-intensity areas, for which microcredit loans would be preferable, or crowd funding from a non-refundable form of grant. Correspondingly, a growing company could receive either a capital boost or an investment loan guarantee in combination with a grant. The above cases are illustrated in the diagram below and can be a springboard for the design and formulation of policies that can meet the real needs of businesses. This is something that the prevailing horizontal actions of state aid and financial instruments cannot cover. 
However, this paper is an attempt to record the financial tools designed and implemented for EU countries in recent years, which coincided with the prolonged global economic crisis and the reaction of major economic regions of the world (USA, EU, BRICs, etc.) to her. In this context, the author points out some issues that need to be addressed at the central level of financial instrument planning as part of public policies that highlight the state's interventionist role in promoting entrepreneurship as a lever for achieving sustainable economic growth in the long run.

The wider use of these SMEs' financial instruments requires a complete change of political-economic targeting, from the one-dimensional long-term support of infrastructure projects towards strengthening the productive base and innovative and extroverted entrepreneurship. The latter, however, should not be seen as a solution of necessity, but as a lever in support of sustainable development with a social sign and not exclusively and only in terms of efficiency. In a mix of policy measures aimed at long-term economic growth, financial instruments can be an important means of supporting small and medium-sized enterprises.

The tendency of borrowing funds mainly towards working capital loans, may to some extent meet the short-term needs of EU SMEs during the economic crisis and the prolonged recession of some European economies, but failed to meet investment needs there. It is crucial to realize that in the long run, investment is what creates the conditions for economic recovery through GDP growth and a reduction in the unemployment rate. In addition, there is no clear picture of whether part of the funds were ultimately used by banks to refinance past loans to their client companies, contrary to the EU state aid regulatory framework.

Finally, from the findings of this paper (spanning years 2014 to 2020), increasing the percenatge of SME financial programmes in the EU budget analyzed under the scope of EU targets from the year 2021 to 2027 and furthering the programmes to include SMEs other than of the member countries, are surelly considered as quite significant steps regarding the future of SMEs.

\section{References}

Armingeon, K., \& Guthmann, K. (2014). Democracy in crisis? The declining support for national democracy in European countries, 2007-2011. European Journal of Political Research, 53(3), 423-442. https://doi.org/10.1111/1475-6765.12046

Auf dem Brinke, A., \& Enderlein, H. (2017). How to make sense of the structural reform lists for the euro area. Jacques Delors Institut - Berlin, Policy Paper 184.

Berger, H., Dell'Ariccia, G., \& Obstfeld, M. (2018). Revisiting the economic case for fiscal union in the euro area. Retrieved

from https://www.imf.org/en/Publications/Departmental-Papers-Policy-Papers/Issues/2018/02/20/Revisiting-the-Eco nomic-Case-for-Fiscal-Union-in-the-Euro-Area-45611

Bordo, M., Markiewicz, A., \& Jonung, L. (2011). A fiscal union for the euro: some lessons from history. NBER Working Paper No. 17380.

Charbit, C. (2011). Governance of public policies in decentralised contexts: the multi-level approach. OECD Regional Development Working Papers, 2011/04.

D'Alfonso, A., \& Stuchlik, A. (2016). A fiscal capacity for the euro area? Options for reforms to counter asymmetric shocks. Retrieved from https://infoeuropa.eurocid.pt/files/database/000060001-000061000/000060063.pdfhttp://www.europarl.europa.e u/thinktank/en/document.html?reference=EPRS_IDA\%282016\%29589774

Daniele, G., \& Geys, B. (2015). Public support for European fiscal integration in times of crisis. Journal of European Public Policy, 22(5), 650-670. https://doi.org/10.1080/13501763.2014.988639

Delors, J. (2013). Rethinking the EMU and making greater Europe positive again. Tribune, Notre Europe - Jacques Delors Institute. In S. Dullien, \& F. Fichtner (Eds.), A common unemployment insurance system for the euro area. DIW Economic Bulletin, 3(1), 9-14.

EC (European Commission). (2019a). EU budget. Retrieved from https://ec.europa.eu/info/abouteuropean-commission/eu-budget_en

EC. (2014). Horizon 2020 in $\quad$ brief. $\quad$ Retrieved from https://ec.europa.eu/programmes/horizon2020/sites/horizon2020/files/H2020_inBrief_EN_FinalBAT.pdf

EC. (2019b). EU expenditures and revenues 2014-2020. Retrieved from http://ec.europa.eu/budget/graphs/revenue_expediture.html 
EC.

(2019c)

About

EIF.

Retrieved

from

https://ec.europa.eu/commission/news/investment-plan-europeeif-and-mutualite-de-cautionnement-sign-first-co sme-agreement-smes-luxembourg-2018-feb-05_en/

EC. (2019d). EU programme for employment and social innovation (EaSI). Retrieved from https://ec.europa.eu/social/main.jsp?catId=1081\#navItem-2/

EC. (2019e). A new financial instrument for SMEs. Retrieved from https://ec.europa.eu/digital-singlemarket/en/financial-guarantee-facility-culture-creative/

EIB (European Investment Bank). (2019a). European investment bank EIB by the numbers. Retrieved from https://www.eib.org/en/index.htm

EIB. (2019b). European investment bank, sectors. Retrieved from https://www.eib.org/en/projects/sectors/index.htm

EIB. (2019c). What is the European fund for strategic investments (EFSI). Retrieved from https://www.eib.org/en/efsi /what-is-efsi/index.htm/

EIB. (2019d). What's the focus of EFSI?. Retrieved from https://www.eib.org/en/efsi/what-is-efsi/index.htm/EIF EIF. (2019b). SMEs and innovation at heart join the EIF. Retrieved from https://www.eif.org/jobs/index.htm/

Eichengreen, B., \& Wyplosz, C. (2017). Europe's fiscal conundrum. In A. Bınassy-Quirı, \& F. Giavazzi (Eds.), Europe's political spring: fixing the Eurozone and beyond (pp. 61-68). London, UK: CEPR Press.

EIF (European Investment Fund). (2019a). Regulation (EU) No 1287/2013 of the European parliament and of the council. Retrieved from https://eurlex.europa.eu/legalcontent/ $\mathrm{EN} / \mathrm{TXT} / \mathrm{PDF} /$ ?uri=CELEX:32013R1287\&from=EN/

EU. (2019a). About COSME. Retrieved from https://ec.europa.eu/easme/en/cosme/cosme-fundingopportunities

EU. (2019b). Europe Union funds. Retrieved from https:// europa.eu/youreurope/ business/financefunding/getting-funding/access-finance/index_en.htm\#shortcut-4-eu-funds/

EU. (2019c). Creative growth. Retrieved from http://www.creative-growth.eu/Portals/10/Creative_Growth_Recommendations_Final_20111006.pdf/

EU. (2019d). How the EU budget is spent. Retrieved from https://europa.eu/european-union/about-eu/eu-budget/expenditure_en

European Commission. (2017). Report from the commission to the parliament and the council on trade and investment barriers. Retrieved from http://trade.ec.europa.eu/doclib/docs/2018/june/tradoc_156978.pdf

European Commission. (2018a). Overview of FTA and other trade negotiations. Retrieved from http://trade.ec.europa.eu/doclib/docs/2006/december/tradoc_118238.pdf

European Council. (2019). Multiannual financial framework for 2014-2020. Retrieved from https://www.consilium.europa.eu/en/policies/eu-budgetary-system/multiannual-financial-framework/mff-2014$2020 /$

European Parliament. (2019). The budgetary procedure. Retrieved from http://www.europarl.europa.eu/factsheets/en/sheet/10/the-budgetary-procedure

Franks, J., Barkbu, B., Blavy, R., Oman, W., \& Schoelermann, H. (2018). Economic convergence in the euro area: coming together or drifting apart?. IMF Working Papers, WP18/10.

Keller, E. (2018). From Meseberg to nowhere? A Franco-German impetus for the Eurozone. Visions franco-allemandes, 29, Ifri, November.

Krugman, P. (1993). Lessons of Massachusetts for EMU. In F. Torres, \& F. Giavazzi (Eds.), Adjustment and growth in the European Monetary Union (pp. 241-266). London, UK: Cambridge University Press. https://doi.org/10.1017/CBO9780511599231.016

Musgrave, R. A. (1939). The voluntary exchange theory of public economy. The Quarterly Journal of Economics, 53(2), 213-237. https://doi.org/10.2307/1882886

Oates, W. (1972). Fiscal federalism. New York: Harcourt Brace Jovanovich.

Oates, W. (1999). An essay on fiscal federalism. Journal of Economic Literature, 37(3), 1120-1149. https://doi.org/10.1257/jel.37.3.1120 
Pisani-Ferry, J., Sapir, A., \& Wolff, G. (2013). EU-IMF assistance to euro-area countries: an early assessment. Blueprints, Bruegel, number 779.

Rubio, A. (2013). Which financial instrument to facilitate structural reforms in the euro area?. Jacques Delors Institut - Berlin, Policy Paper 104.

Wiener, A., Berzel, T. A., \& Risse, T. (2018). European integration theory (3rd ed.). Oxford, UK: Oxford University Press. https://doi.org/10.1093/hepl/9780198737315.001.0001

Wolf, G. (2017). Eurozone or EU budget? Confronting a complex political question. Retrieved fromhttp://www.worldcommercereview.com/html/wolff-eurozone-or-eu-budget-confronting-a-complexpolitical -question.htm

\section{Copyrights}

Copyright for this article is retained by the author(s), with first publication rights granted to the journal.

This is an open-access article distributed under the terms and conditions of the Creative Commons Attribution license (http://creativecommons.org/licenses/by/4.0/). 